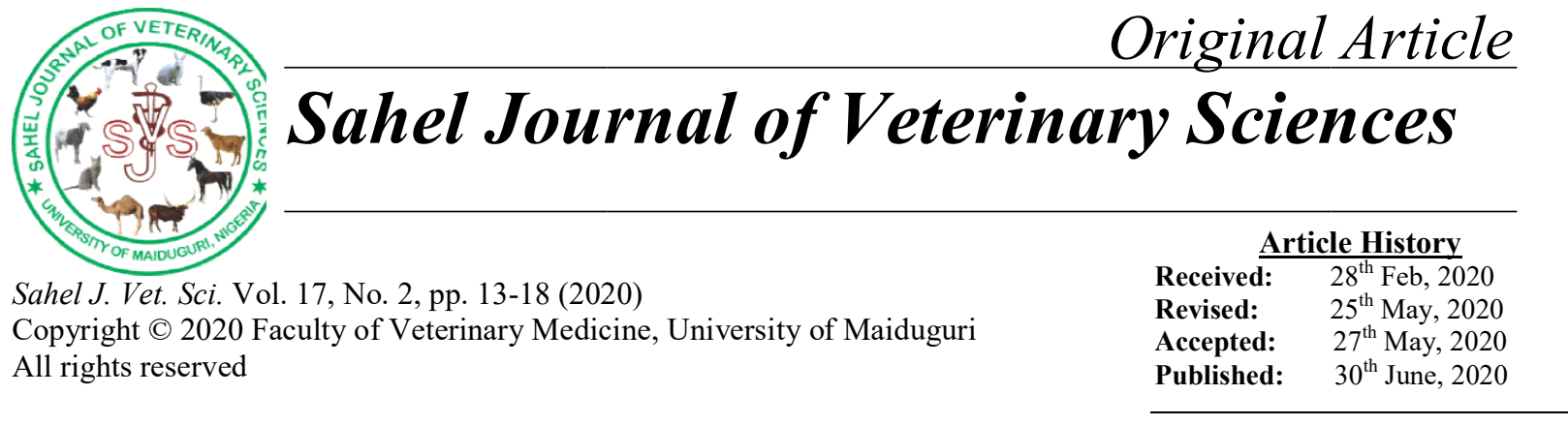

\title{
Incidence of Aflatoxin B1 in Commercial Poultry Feed and Tissues of Broiler Chickens in Ibadan, Nigeria
}

\author{
${ }^{1}$ Olatoye, O. I., ${ }^{2}$ Aiyedun, J. O. and ${ }^{2 *}$ Oludairo, O. O.
}

\begin{abstract}
${ }^{1}$ Department of Veterinary Public Health and Preventive Medicine, Faculty of Veterinary Medicine, University of Ibadan, Ibadan, Nigeria ${ }^{2}$ Department of Veterinary Public Health and Preventive Medicine, Faculty of Veterinary Medicine, University of Ilorin, Ilorin, Nigeria

*Author for Correspondence:oludairo@hotmail.com

ABSTRACT

Aflatoxin B1 (AFB1) belongs to a group of hepatocarcinogenic and hepatotoxic mycotoxin produced by Aspergillus flavus and Aspergillus parasiticus found in food or feed products. In this study we analyzed 180 feed of six different brands of commercial poultry feeds from three feed distribution outlets in Ibadan, southwest Nigeria for the occurrence and concentrations of AFB1. In addition, to the transfer of AFB1 to broiler meat from chicken fed for four weeks with one brand of feed associated with the highest AFB1 contamination. The study was carried out between April and June, 2019. The presence/concentration of AFB1 was determined using High Performance Liquid Chromatography (HPLC) following solid phase extraction of sample and preparation. Aflatoxin B1 was detected in all (100\%) the brands of feed and $48 \%$ of chicken samples tested. The concentration of AFB1 in feed ranged between $10.5 \pm 4.0$ and $47.78 \pm 6.4$, while the mean AFB1 residues obtained in chicken muscle, gizzards and liver after four weeks were $0.07 \pm 0.02,0.18 \pm 0.05$ and $0.13 \pm 0.02 \mu \mathrm{g} / \mathrm{kg}$, respectively. The presence of AFB1 in all the brands of poultry feeds tested in this study and its possible transfer into chicken meat poses food/feed safety and public health concern. There is therefore, the need to screen feed and apply Hazard Analysis Critical Control Point to feed manufacturing, storage and broiler chicken production to prevent aflatoxicosis.
\end{abstract}

Keywords: Incidence; Commercial poultry feed; Broiler chicken; Aflatoxicosis; Mycotoxin

\section{INTRODUCTION}

Aflatoxins are mycotoxins produced by strains of Aspergillus flavus and A. parasiticus (Sarma et al., 2017). These fungi are relatively ubiquitous (Adeniran et al., 2013). Climatic factors such as high temperature and humidity aid the growth and spread of these fungi (Moss, 1992; Rodrigues and Nosanchuk, 2020). They are commonly found in cereals such as maize, sorghum, guinea corn and plant protein such as soya bean meal, groundnut cake and cotton seed cake (Halfon-Meiri and Barki, 1990; Herrman, 2002). These are the major constituents of commercial poultry feed in Nigeria (Akande et al., 2006; Hanif et al., 2006). Feed storage in tropical humid high temperature also enhances the growth of Aflatoxin producing Aspergillus resulting in contamination (Marijani et al., 2019).

Aflatoxin B1 (AFB1) is the most prevalent toxin in cereals used in feeds and presents the greatest toxigenic threat to chicken and humans (Prithi et al., 1992; Azzam and Gabal, 1997; Kpodo et al., 2000; Osho et al., 2007; Lesilie et al., 2008). Animal feed contamination with Aflatoxin B1 (AFB1) constitute a significant public health risk along the food chain (IARC, 1993; Azzam and Gabal, 1998; Verma, 2004; Del et al., 2005; Njobeh et al., 2009; Essono et al., 2009; Herzallah, 2013). AFB1 is known to be carcinogenic and teratogenic in addition to being the most harmful form of aflatoxin due to its direct link to the cause of human liver cancer (Leslie et al., 2008; USAID 2012; Sarma et al., 2017).

Poultry production in Nigeria has its hub in Ibadan, Nigeria where poultry birds and inputs, including different commercial brands of feed are produced and distributed across the country (Oluwole et al., 2012). Feed ingredients are obtained from different sources that are of variable qualities which could also determine the contamination and safety of poultry feeds (Maciorowski et al., 2007). Aflatoxin B1 is a poultry feed contaminant that impairs all important poultry production parameters including feed intake, feed conversion efficiency, weight gain, pigmentation, male/female reproductive performance, processing yield and egg production (Klich, 2002; Rathod et al., 2013). The toxin 
has been shown to be transferred from poultry feed to muscles, kidney, liver tissues and eggs of chicken via consumption (Chang and Hamilton, 1982; Herzallah, 2013). It is therefore important to ensure safety of feed to poultry and ultimately the consumers of poultry products. This study determined the occurrence and contamination levels of AFB1 in major brands of commercial poultry feeds commonly sold in Ibadan and the concentration of AFB1 in the tissues of broilers chickens fed with a brand of the contaminated feed.

\section{MATERIALS AND METHOD \\ Ethical Statement}

Ethical approval was obtained from the Animal Care and Use Research Ethics Committee (ACUREC) of the University of Ibadan with assigned number UI-ACUREC/18/0105.

\section{Sample Area}

Ibadan, southwest Nigeria was chosen for this study due to high volume of poultry production and consumption in this region of the country (Oluwole et al., 2012). Several commercial poultry farms, feeds manufacturers and distributors are located in this region. Also, it has a favorable climate for the growth of Aspergillus spp. and subsequent production of AFB1 with an average annual temperature of $26^{\circ} \mathrm{C}$ and humidity of $85 \%$.

\section{Sample Collection}

A Complete Randomized Design (CRD) was employed for data collection. A total of 180 feed samples from six commonly available commercial brands of broiler feed were randomly collected from three retail outlets in Ibadan. One pooled sample comprising ten samples of each brand of feed were collected from each of the six brands of feed $(\mathrm{A}-\mathrm{F})$ in each visit. Making six pooled samples comprising of sixty feed samples per visit and a total of eighteen pooled samples culminating in one hundred and eighty samples from the six brands of feed from the three visits. The samples were obtained in April, June and July 2019 with a minimum of four weeks in between each visit for sample collection. Each pool of samples was analysed in triplicate to obtain the mean concentrations in each brand/visit. Samples were collected in Nasco $^{(\mathrm{R})}$ sample whirl bags and tightly sealed. Also, a total of 75 fresh broiler meat samples (25 each for breast muscle, gizzard and liver) were obtained from 25 market sized broilers randomly obtained from commercial farms that fed chicken with one of the brands of sampled commercial feeds for a minimum of four weeks. All samples were transported to Food and Meat Hygiene Laboratory, University of Ibadan for sample preparation. Aflatoxin B1 analysis was subsequently carried out using High Performance Liquid Chromatography (HPLC) at the Nigerian Institute of Laboratory Science Technology (NILST) in Ibadan.

\section{Sample Preparation and Clean-up Procedures}

The feed and meat samples were grinded into fine powder and paste with Warin blender and stored at $-4^{\circ} \mathrm{C}$ and $-18^{\circ} \mathrm{C}$ respectively until subsequent extraction and analysis (Urraca et al., 2004). Extraction process involved homogenization of $20 \mathrm{~g}$ of each feed sample with $2 \mathrm{~g} \mathrm{NaCl}$ and $100 \mathrm{ml}$ of methanol: water solution (80:20) in a blender for 3 minutes. After which one cover was removed and the extract filtered with Whatman No. 1 filter paper (Ige et al., 2012; Wacoo, 2014). Approximately $20 \mathrm{ml}$ of the filtrate was transferred into a conical flask to which $60 \mathrm{ml}$ of $10 \%$ phosphate buffer solution ( $\mathrm{pH}$ 7.4) was added and mixed thoroughly. The diluted extract was filtered into another conical flask using the glass microfilter after which $20 \mathrm{ml}$ of the solution was passed through Solid Phase Extraction (SPE) in Immuno Affinity Column (IAC). Aflatoxin B1 analyte was eluted into $5 \mathrm{~mL}$ volumetric flask in addition with $1 \mathrm{~mL}$ of methanol ready for HPLC analysis (AOAC, 2000; Abd El Monem et al., 2015).

\section{HPLC Determination}

Detection and quantification of AFB1 was performed by Agilent HPLC equipped with binary HPLC pump. Thermo LC-Si model column of $250 \times 4.6 \mathrm{~mm}$ kept in column oven at $40^{\circ} \mathrm{C}$ and fluorescence detector (Model FL 2475) set at wavelength 365 and $425 \mathrm{~nm}$ for excitation and emission respectively were used. The mobile phase for isocratic comprised of toluene, ethyl acetate, formic acid and methanol $(90: 5: 2.5: 2.5, \mathrm{v} / \mathrm{v} / \mathrm{v} / \mathrm{v})$ at flow rate of $2.0 \mathrm{~mL} / \mathrm{min}$. The results were confirmed by Agilent HPLC equipped with fluorescent detector and run under similar conditions.

Standard Curve Preparation and Recovery of AFB1 Spiked

Aflatoxin B1 standard (0.26 ng/ $\mu$ l) (Supelco \# 46304-U) was prepared according to AOAC Official methods (AOAC, 2000). The solution was diluted in ratio 1:10 (100 $\mu 1$ of 2.6 $\mathrm{ng} / \mu \mathrm{l}$ stock with $900 \mu \mathrm{l}$ methanol) to make a $0.26 \mathrm{ng} / \mu \mathrm{l}$ aflatoxin B1 standard. Afterwards, the $0.26 \mathrm{ng} / \mu 1$ aflatoxin B1 standard was further diluted at ratio 1:10 (100 $\mu 1$ of 0.26 $\mathrm{ng} / \mu \mathrm{l}$ stock with $900 \mu \mathrm{l}$ methanol) to make a $0.026 \mathrm{ng} / \mu \mathrm{l}$ aflatoxin B1 standard. The calibration curve of peak is as against the corresponding concentrations of aflatoxin B1 standards was created using Microsoft ${ }^{\circledR}$ Excel ${ }^{\circledR} 2013$ version 15.0.5249.1000. The peak areas of the analytes from the samples unknown were used to calculate the concentrations in (ppb) using linear regression $(\mathrm{Y}=\mathrm{mX}+\mathrm{b})$ where: $\mathrm{Y}=$ peak area/height; $\mathrm{x}=$ analyte concentration in $\mathrm{ppb} / \mu / \mathrm{kg} ; \mathrm{m}=$ slope of curve; and $\mathrm{b}=$ intercept of $\mathrm{y}$.

\section{Recovery of Aflatoxin B1}

The solutions were stored in Teflon capped $2 \mathrm{~mL}$ amber vials away from light and at $-18^{\circ} \mathrm{C}$. Blank feed samples (corn) were spiked with serially diluted standard AFB1. Spiked samples were allowed to dry for 30 minutes in the hood before assaying following same extraction above. Recovery of the aflatoxin B1 was done using a blank feed sample spiked with standard solution of AFB1 and the resultant contamination level recorded. A linear AFB1 calibration curve was plotted and the correlation coefficient determined.

\section{Statistical Analyses}

The AFB1 residues concentrations in the selected brands of poultry feed and different meat types were subjected to ANOVA with Duncan's Multiple Range Test using the general linear model (GLM) procedure in PC-SAS version 9.0. Values were considered significant if $\mathrm{p}<0.05$.

\section{RESULTS}

\section{Feed Sample Aflatoxin B1 Contamination}

Out of the tested feed samples brand D feed samples had the highest AFB1 contamination of $47.78 \pm 6.4$ while the lowest 
mean concentration $10.56 \pm 4.0 \mu \mathrm{g} / \mathrm{kg}$ was obtained from brand F. Table 1 showed mean AFB1 concentrations in the six brands of poultry feed tested. A linear AFB1 calibration curve was obtained with correlation coefficient of 0.999 and the coefficient of variation $(\mathrm{CV})$ of $1.32 \%$ with minimum detection limit of $0.05 \mu \mathrm{g} / \mathrm{kg}$. The concentration of AFB1 in the meat samples ranged from $0.07-0.18 \mu \mathrm{g} / \mathrm{kg}$ with gizzards having the highest concentration of $0.18 \pm 0.05$ $\mu \mathrm{g} / \mathrm{kg}$ (Table 2). The recoveries were generally higher than $80 \%$, ranging from 85 to $93 \%$.

\section{Analysis of Feed and Tissue Samples}

Table 3 showed the results of analysis of variance of AFB1 concentrations in the six brands of feeds. There was significant difference $(p<0.05)$ in the concentration of Aflatoxin B1 (AFB1) between commercial feed A and that of commercial feeds $\mathrm{D}$ and feed $\mathrm{F}$. There was significant difference $(\mathrm{p}<0.05)$ between the level of AFB1 in commercial feeds $\mathrm{B}$ and $\mathrm{A}, \mathrm{D}, \mathrm{E}$ and $\mathrm{F}$, except brand $\mathrm{C}$ where the $\mathrm{p}$ value $>0.05$. Feed brand $\mathrm{C}$ showed significant difference $(p<0.05)$ in the level of AFB1 compared to brands $D$ and $F$ while there was no significant difference $(p>$ 0.05 when compared with feed brands $\mathrm{B}$ and $\mathrm{E}$. The level of AFB1 in brand D feed was significantly different $(p<0.05)$ compared to brands $\mathrm{E}$ and $\mathrm{F}$. There was also significant difference $(\mathrm{p}<0.05)$ in the level of AFB1 between feed brands E and F (Table 3).

Table 1: Aflatoxin B1 Contamination Level $(\mu \mathrm{g} / \mathrm{kg})$ in Commercial Poultry Feed.

\begin{tabular}{llc}
\hline $\mathbf{S} / \mathbf{N}$ & $\begin{array}{l}\text { Commercial Brands of Broiler Finisher } \\
(\mathbf{N}=\mathbf{1 8 0})\end{array}$ & $\begin{array}{l}\text { Mean AFB1 Levels } \\
(\boldsymbol{\mu g} / \mathbf{~ k g})\end{array}$ \\
\hline 1 & Feed A $(\mathrm{n}=30)$ & $28.67 \pm 8.9$ \\
\hline 2 & Feed B $(\mathrm{n}=30)$ & $35.00 \pm 3.6$ \\
\hline 3 & Feed C $(\mathrm{n}=30)$ & $30.00 \pm 3.7$ \\
\hline 4 & Feed D $(\mathrm{n}=30)$ & $47.78 \pm 6.4$ \\
\hline 5 & Feed E $(\mathrm{n}=30)$ & $27.11 \pm 5.8$ \\
\hline 6 & Feed F $(\mathrm{n}=30)$ & $10.56 \pm 4.0$ \\
\hline
\end{tabular}

Table 2: Aflatoxin B1 Content of Chicken Meat from Broilers Fed with Brand D Commercial Feeds for 4 Weeks

\begin{tabular}{llc}
\hline $\mathbf{S} / \mathbf{N}$ & Chicken Tissue $\mathbf{N}=\mathbf{7 5}$ & Mean AFB1 Levels $(\boldsymbol{\mu g} / \mathbf{~ k g})$ \\
\hline 1 & Chicken breast $(\mathrm{n}=25)$ & $0.07 \pm 0.02$ \\
\hline 2 & Gizzard $(\mathrm{n}=25)$ & $0.18 \pm 0.05$ \\
\hline 3 & Liver $(\mathrm{n}=25)$ & $0.13 \pm 0.02$ \\
\hline
\end{tabular}

\section{DISCUSSION}

The importance of food safety cannot be over emphasised. The danger posed by AFB1 in animals and humans is immense because of its carcinogenic and teratogenic nature. The occurrence of AFB1 in the sampled commercial poultry feeds was confirmed with positive samples discovered in all the sampled brands. The mean levels of AFB1 in five of the sampled brands were higher than the United States Food and Drug Administration (FDA, 2019) recommended level of 20 $\mu \mathrm{g} / \mathrm{kg}$. The contributory factor to the level of incidence of AFB1 in samples analysed in this study maybe the time of collection of samples was between the months of April and July and it coincided with rainy season in Nigeria. It is an established fact that conditions of high humidity contribute to increased production of Aflatoxins by Aspergillus spp. In a similar study carried out by Rashid et al. (2012), the maximum level of AFB1 detected in finished commercial feed was $166 \mu \mathrm{g} / \mathrm{kg}$ while the minimum was $10 \mu \mathrm{g} / \mathrm{kg}$. The significant difference in the levels of AFB1 in the six brands of feed highlighted the differences in production practices maintained by the different producers.
The findings of this study confirmed the presence of AFB1 in commercial poultry feed which may be attributed to prevalence of poor harvesting techniques, insect infestation of crops, poor storage practices and environmental conditions hence the need for regular monitoring of mycotoxin levels in animal feeds by relevant regulatory agencies (Jones et al., 1994). The transfer of AFB1 from feed unto the muscle tissues of broilers was confirmed by the detection of trace quantities of the toxin in the meat samples of broilers fed with a brand of sampled commercial feeds for four weeks. In another study carried out by Herzallah (2013), where laying birds were fed with AFB1 contaminated feed in increasing dosages for 7 weeks, their eggs and meat were found to be contaminated in the same increasing order of AFB1 dosage in feed served. It was also observed that the levels of AFB1 in the chicken meat parts; gizzard and liver were higher than chicken breast meat which was in tandem with the work of Saltana and Hanif (2009) and Oyero and Oyefolu (2010), where transfer of AFB1 from contaminated concentrates to beef was assessed. According to the study, organs like liver and kidney were more contaminated than beef. 
The same pattern was observed by Herzallah (2013). In this research work however, the level of AFB1 found in the meat samples; chicken breast, gizzard and liver were below the International Safety Limit which is $5 \mu \mathrm{g} / \mathrm{kg}$ (FAO, 2003).
Feeding birds with diets high in AFB1 for long periods of time could lead to higher level of AFB1 residues in the meat and other products such as eggs (FAO, 2003).

Table 3: Analysis of Variance (ANOVA) of AFB1 Concentrations between the Six Brands of Poultry Feed

\begin{tabular}{|c|c|c|c|c|c|c|}
\hline Brands & Groups & & P-value & F-value & Mean Diff. & 95\% C.I. \\
\hline & $\mathrm{A}$ & $\mathrm{B}$ & 0.23 & 39.91 & 6.33 & $11.76-0.89$ \\
\hline & & $\mathrm{C}$ & 0.63 & & 1.33 & $6.76-4.10$ \\
\hline \multirow[t]{5}{*}{$\mathbf{A}$} & & $\mathrm{D}$ & $<0.001$ & & 19.11 & $-24.54-13.67$ \\
\hline & & $\mathrm{E}$ & 0.57 & & 1.56 & $-3.88-6.99$ \\
\hline & & $\mathrm{F}$ & $<0.001$ & & 18.11 & $-12.67-23.54$ \\
\hline & $\mathrm{B}$ & $\mathrm{A}$ & 0.02 & 39.91 & 6.33 & $0.89-11.76$ \\
\hline & & $\mathrm{C}$ & 0.07 & & 5.00 & $0.44-10.43$ \\
\hline \multirow[t]{5}{*}{ B } & & $\mathrm{D}$ & $<0.001$ & & 12.77 & $18.21-7.34$ \\
\hline & & $\mathrm{E}$ & 0.005 & & 7.88 & $2.45-13.32$ \\
\hline & & $\mathrm{F}$ & $<0.001$ & & 24.44 & $19.00-29.88$ \\
\hline & $\mathrm{C}$ & $\mathrm{A}$ & 0.62 & 39.91 & 1.33 & $-4.10-6.76$ \\
\hline & & $\mathrm{B}$ & 0.07 & & 5.00 & $0.43-10.43$ \\
\hline \multirow[t]{5}{*}{$\mathbf{C}$} & & $\mathrm{D}$ & $<0.001$ & & 17.77 & $23.21-12.34$ \\
\hline & & $\mathrm{E}$ & 0.29 & & 2.88 & $2.54-8.32$ \\
\hline & & $\mathrm{F}$ & $<0.001$ & & 19.44 & $14.00-24.88$ \\
\hline & $\mathrm{D}$ & $\mathrm{A}$ & $<0.001$ & 39.91 & 19.11 & $13.67-24.54$ \\
\hline & & $\mathrm{B}$ & $<0.001$ & & 12.77 & $7.34-1821$ \\
\hline \multirow[t]{5}{*}{ D } & & $\mathrm{C}$ & $<0.001$ & & 17.77 & $12.34-23.21$ \\
\hline & & $\mathrm{E}$ & $<0.001$ & & 20.66 & $15.23-26.10$ \\
\hline & & $\mathrm{F}$ & $<0.001$ & & 37.22 & $31.78-42.65$ \\
\hline & $\mathrm{E}$ & $\mathrm{A}$ & 0.56 & 39.91 & 1.56 & $-6.99-3.88$ \\
\hline & & $\mathrm{B}$ & 0.005 & & 7.89 & $2.45-13.32$ \\
\hline \multirow[t]{5}{*}{$\mathbf{E}$} & & $\mathrm{C}$ & 0.29 & & 2.89 & $2.54-8.32$ \\
\hline & & $\mathrm{D}$ & $<0.001$ & & 20.67 & $15.23-26.10$ \\
\hline & & $\mathrm{F}$ & $<0.001$ & & 16.56 & $11.11-21.99$ \\
\hline & $\mathrm{F}$ & $\mathrm{A}$ & $<0.001$ & 39.91 & 18.11 & $12.67-23.54$ \\
\hline & & $\mathrm{B}$ & $<0.001$ & & 24.44 & $19.00-29.88$ \\
\hline \multirow[t]{3}{*}{$\mathbf{F}$} & & $\mathrm{C}$ & $<0.001$ & & 19.44 & $14.00-24.88$ \\
\hline & & $\mathrm{D}$ & $<0.001$ & & 37.22 & $31.78-42.65$ \\
\hline & & $\mathrm{E}$ & $<0.001$ & & 16.55 & $11.11-21.99$ \\
\hline
\end{tabular}

\section{Conclusions}

The presence of AFB1 in poultry feeds and its possible transfer into chicken meat is of food safety and public health importance. It is also a concern to both the poultry and food industry. Aflatoxin B1 could be potential health risk to both chicken and the consumers of chicken and its products. Export of chicken feed with AFB1 concentration of $20 \mu \mathrm{g} / \mathrm{Kg}$ is not acceptable in most part of the world especially Europe and United States of America. There is need to screen chicken feed possibly apply hazard analysis critical control point (HACCP) to feed manufacturing, storage and broiler chicken production in order to prevent the presence of mycotoxins and ensure food safety. It is recommended that monitoring and surveillance of mycotoxin levels in animal feeds and animal products meant for human consumption should be carried out for longer periods and routinely to enhance poultry production.

\section{Authors' contributions}

$\mathrm{OIO}$ and AJO designed and carried out the research. OIO

AJO and OOO were involved in the analysis, writing and proof reading of the manuscript.

\section{Conflict of Interest}

The authors declare that they do not have any conflict of interest. 


\section{REFERENCES}

Abd El Monem M., Ragab M., Maher, M. A., Ali S. H. H., Salah N., Hussien H. M. and Amro F. H. (2015): Detection of aflatoxins in meat by modified HPLC method. Egypt. J. Chem. Environ. Health 1, 945954.

Adeniran L. A, Makun H. A. and Muhammad H. L. (2013): Survey of Mycotoxigenic Fungi in Concentrated Poultry Feed in Niger State, Nigeria. J. Food Res., 2: 128-135.

Akande K. E, Abubakar M. M., Adegbola T. A. and Bogoro S. E. (2006): Nutritional and health implications of mycotoxins in animal feeds: A Review. Pak. J. Nut., 5(5): 398-403.

Association of Official Analytical Chemists (AOAC) (2000): Official Methods of Analysis. 17th Edition, AOAC Gaithersburg, MD, USA. Methods 925.10, 65.17, 974.24, 992.16.

Azzam A. H. and Gabal M. A. (1997): Interaction of aflatoxin in the feed and immunization against selected infectious diseases. Avian Pathology, 26, 317-325. Azzam A. H. and Gabal M. A. (1998): Aflatoxin and immunity in layer hens. Avian Pathol, 27, 570-577.

Chang C. F. and Hamilton P. B. (1982): Increased severity and new symptoms of infectious bursal disease during aflatoxicosis in broiler chickens. Poult. Sci. J., 61, 1061-1068.

Del B. M., Oliveira C. A. F., Albuquerque R., Guerra J. L. and Correa B. (2005): Effects of Prolonged Oral administration of Aflatoxin B1 and Fumonisin B1 in Broiler Chickens. Poult. Sci. J., 84 (12) 1835 1840.

Essono G., Ayodele M., Akoa A., Foko J., Filtenborg O. and Olembo S. (2009): Aflatoxin producing Aspergillus spp. and aflatoxin levels in stored cassava chips as affected by processing practice. Food Control, 20, 648-654.

Figueroa S., Centeno S., Calvo M. A., Rengel A. and Adelantado C. (2009): Mycobiodata and concentration of Ochratoxin $\mathrm{A}$ in concentrated poultry feed from Venezuela. Pak. J. Biol. Sci., 12(7), 589-594.

Filtenborg O., Frisvad T. C. and Samson R. A. (2000): Specific association of fungi in foods and influence of

physical environmental factors. In R. A. Samson, E. S. Hoekstra, J. C. Frisvad, \& O. Filtenborg

(Eds.), Introduction to Food-and Airborne Fungi (6th Ed., pp. 306-320).

Food and Agricultural Organization (FAO) (2003): Manual on the application of the HACCP system in mycotoxin prevention and control (1st Ed.). Rome: Food and Agriculture Organisation of the United Nation. Available at: http://www.fao.org/3/ay1390e.pdf. Accessed 28th February, 2020.

Food and Drug Administration (FDA) (2019): CPG Sec. 683.100 Action Levels for Aflatoxins in Animal Feeds. Available https://www.fda.gov/media/121202/download. Accessed on 10th February, 2020.
Halfon-Meiri A. and Barki G. (1990): Mycoflora involved in seed germ discolouration of popcorn and its effect on seed quality. Mycopathologia, 11, 37-41.

Hanif N. Q. M., Naseem S. K. and Malik N. (2006): Prevalence of mycotoxins in poultry rations. Pak. J. Sci. Ind. Res., 49: 120-124.

Herrman T. (2002): Mycotosins in feed grains and ingredients. Department of Grain Science and

Industry, Kansas State University Agricultural Experiment Station and Cooperative Extension, MF-206. Available at: https://www.plantpath.kstate.edu/extension/publications/mf-2061.pdf. Accessed 27th February, 2020

Herzallah S. M. (2013): Aflatoxin B1 Residues in Eggs and Flesh of Laying Hens Fed Aflatoxin B1 Contaminated Diet. Am. J. Agric. Biol. Sci., 8 (2): 156-161, 2013 ISSN: 1557-4989

Ige E. A., Ogundero V. W. and Agu G. C. (2012): Evaluation of aflatoxin content of naturally occurring molds from poultry feeds. Afr. J. Food Sci., 6 (2): 104-110. International Agency for Research on Cancer (IARC) (1993): IARC monographs on the evaluation of carcinogenic risks to humans: some naturally occurring substances, food items and constituents, heterocyclic aromatic amines and mycotoxins. Ochratoxin A. International Agency for Research on Cancer, 56, 26-32.

Jones F. T., Genter M. B., Hagler W. M., Hansen J. A. and Mowrey B. B. (1994): Understanding and coping with effects of mycotoxins in livestock feed and forage. North Carolina Cooperative Extension Services (p. 114). Carolina.

Klich M. A. (2002): Introduction; economic and medical importance of Aspergillus. In Identification of common Aspergillus species (pp. 1-16). Centraal bureau voor Schimmel culture, Utrecht: The Netherlands (Publishers) www.ccsenet.org/jfr J. Food Res., 2 (2), 2013.134.

Kpodo K., Thrane U. and Hald B. (2000): Fusaria and fumonisins in maize from Ghana and their cooccurrence with aflatoxins. Intl. J. Food Microbiol., 61: 147-157.

Leslie J. F, Bandyopadhyay R. and Visconti A. (2008): eds. Mycotoxins: Detection Methods, Management, Public Health and Agricultural Trade. C.A.B. International DOI: 10.1079/9781845930820.0000. Available at: https://www.cabi.org/cabebooks/ebook /20083189556. Accessed 27th February, 2020

Maciorowski K. G., Herrera P., Jones F. T., Pillai S. D. and Rickie S. (2007): Effects on poultry and livestock of feed contamination with bacteria and fungi. Anim. Feed Sci. Technol. 133(1): 109 - 136.

Marijani E., Kigadye E. and Okoth S. (2019): Occurrence of Fungi and Mycotoxins in Fish Feeds and their impact on fish health. Int. J. Microbiol. doi.org/10.1155/2019/6743065. Available at: http://downloads.hindawi.com/journals/ijmicro/2019 /6743065.pdf. Accessed 27th February, 2020. 
Moss M. O. (1992): Mycotoxic fungi. In: Microbial Food Poisoning. In A. R. Elley (Ed.), Chapman and Hall; pp 73-106.

Njobeh B. P., Dutton M. F., Koch S. H. and Chuturgoon A. (2009). Contamination with storage fungi of human foods. Int. J. Food Microbiol., 135: 193-198.

Oluwole O. E., Emikpe B. O. and Olugasa B. O. (2012): Attitude of poultry farmers towards vaccination against Newcastle disease and avian influenza in Ibadan, Nigeria. Sokoto J. Vet. Sci., 10 (2): 4-12.

Osho I. B., Awoniyi T. A. M. and Adebayo A. I. (2007): Mycological investigation of compound poultry feeds used in poultry farms in south west Nigeria. Afr. J. Biotechnol., 6: 1833-1836.

Oyero G. O. and Oyefolu A. B. (2010): Natural occurrence of aflatoxin residues in fresh and sun-dried meat in Nigeria. Pan Afr. Med. J., Available online at https://www.ncbi.nlm.nih.gov/pmc/articles/PMC317 2626/. Accessed 10 ${ }^{\text {th }}$ February, 2020.

Rashid N., Bajwa M. A., Rafeeq M., Khan M. A., Ahmad Z., Tariq M. M., Wadood A. and Abbas F. (2012): Prevalence of Aflatoxin B1 in finished commercial broiler feed from West Central Pakistan, J. Anim. Plant Sci., 22: 6-10.

Rathod P. R., Kulkarni G. B. and Gangane G. (2013): Pathological effect of low grade Aflatoxicity in Broilers. The Bioscan 8(3): 1115-1118, 2013 (Supplement on Toxicology).
Rodrigues M. L. and Nosanchuk J. D. (2020). Fungal diseases as neglected pathogens: A wake-up call to public health officials. PLoS Negl. Trop. Dis. 14(2): e0007964.

Sarma U. P., Bhetaria P. J., Devi P. and Varma A. (2017). Aflatoxins: Implications on Health. Indian J. Clin. Biochem., 32 (2):124-133.

Urraca J. L., Marazuela M.C. and Moreno-Bondi M.C. (2004): Analysis for zearalenone and a-zearalenol in cereals and swine feed using accelerated solvent extraction and liquid chromatography with fluorescence detection. Anal Chim Acta, 524: 175183.

USAID (2012): Aflatoxin: A Synthesis of the Research on Health, Agriculture and Trade. Available at: https://pdf.usaid.gov/pdf_docs/PBAAH773.pdf. Accessed May 27, 2020.

Verma R. J. (2004): Aflatoxins cause DNA damage. Int. J. Hum. Genet., 4(4): 231-236..

Wacoo A. P., Wendiro D,, Vuzi P. C. and Hawumba J. F. (2014): Methods for Detection of Aflatoxins in Agricultural Food Crops. J. Appl. Chem., 15p. 